\title{
RANCANG BANGUN PROTOTIPE SISTEM MONITORING VENDING MACHINE BERBASIS INTERNET OF THINGS
}

\author{
Virandi Aries Prasetya ${ }^{1 *}$, I Nyoman Piarsa ${ }^{2}$, Dewa Made Sri Arsa ${ }^{3}$ \\ ${ }^{123}$ Program Studi Teknologi Informasi, Fakultas Teknik, Universitas Udayana, Bali \\ e-mail: ${ }^{1}$ ariesprasetya@ student.unud.ac.id, ${ }^{2}$ manpits@unud.ac.id, ${ }^{3}$ dewamsa@unud.ac.id
}

\begin{abstract}
Abstrak
Vending Machine atau mesin penjual otomatis merupakan suatu alat yang dapat menjualkan produknya secara otomatis seperti makanan, minuman, mainan, dan lain-lain. Pada sistem pengoperasian Vending Machine saat ini masih membaca manual penghasilan dari setiap unit dan tidak bisa melihat stok yang tersisa didalam Vending Machine secara online, yang mengakibatkan kurangnya efisiensi kerja petugas yang membawa stok makanan lebih menuju Vending Machine dan pada sistem pemabayaran yang digunakan saat ini masih menggunakan uang kertas, dimana metode ini masih belum efektif dikarenakan saat melakukan transaksi pelanggan tidak bisa menerima uang kembalian dan tidak semua uang kertas bisa terbaca oleh mesin dikarenakan kondisi uang yang berbeda. Oleh sebab itu di buatkannya prototipe ini dengan menambahakan Teknologi IoT atau Internet of Things kedalam Vending Machine, dimana sistem yang akan dibuat dapat melihat data transaksi, data stok dan data penjualan tiap bulannya secara online melalui website maupun telegram dan merubah sistem pembayaran yang sebelumnya menggunakan uang kertas kini menggunakan kartu, agar pelanggan tidak perlu menyiapkan uang pas atau memilih uang yang masih bagus untuk melakukan transaksi. Disimpulkan dengan penerepan Teknologi IoT atau Internet of Things dapat memiliki keuntungan dari pihak pengelola maupun calon pelanggan saat melakukan transaksi.
\end{abstract}

Kata kunci-Mesin Penjual Otomatis, Uang Elektronik, IoT.

\begin{abstract}
A vending machine or vending machine is a tool that can sell its products automatically such as food, drinks, toys, and others. In the current Vending Machine operating system, they still read the income manual for each unit and cannot see the remaining stock in the Vending Machine online, which results in a lack of efficiency in the work of officers who bring more food stock to the Vending Machine and the payment system currently used is still using paper money, where this method is still ineffective because when making a transaction the customer cannot receive change and not all banknotes can be read by machines due to different money conditions. Therefore, he made this prototype by adding IoT or Internet of Things technology to the Vending Machine, where the system to be created can view transaction data, stock data and sales data every month online via a website or telegram and change the payment system that previously used money. paper now uses cards, so customers don't need to prepare the exact amount or choose money that is still good for making transactions. It can be concluded that with the advancement of IoT or Internet of Things technology, it can have advantages for the manager and prospective customers when making transactions.
\end{abstract}

Keywords-Vending Machine, Emoney, IoT. 


\section{PENDAHULUAN}

Mesin Penjual Otomatis atau (Vending Machine) merupakan sebuah mesin penjualan yang akan mengeluarkan item berupa barang atau minuman, setelah pembeli berhasil memasukan uang dengan nominal sesuai dengan item yang akan dibeli [1]. Vending Machine merupakan sebuah objek yang akan bernilai lebih jika diaplikasikan pada konsep IoT. Internet of thing (IoT) merupakan suatu teknologi yang dapat memperluas manfaat dan fungsional dari konektivitas internet itu sendiri [2]. Jika melihat konsep IoT tersebut, banyak kelebihan yang bisa diperoleh oleh pihak pemilik Vending Machine. Keuntungan keuntungan tersebut adalah salah satunya dapat mengurangi biaya operasional mesin, memudahkan pembeli melakukan transaksi, dapat memonitoring stok pada Vending Machine. Untuk membuat sebuah perangkat berbasis Internet of Things, dibutuhkan sebuah prototyping board yang akan digunakan untuk menguji alat tersebut dan melakukan pengembangan

pengembangan yang diperlukan sebelum alat dapat dipasarkan secara luas. NodeMCU merupakan salah satu dari Microcontroller yang ada di pasaran. Ada berbagai alasan mengapa NodeMCU begitu populer di kalangan para praktisi perangkat keras dikarenkan pada board NodeMCU sudah tertanam modul wifi yang dapat memudahkan konektifitas saat membuat suatu alat dan harga relatif murah jika di bandingkan dengan Raspberry PI [3]. Digunakanya Mikrokontroller tersebut dalam pembuatan prototipe yang akan dibuat ini yaitu, mikrokontroller tersebut sudah tertanam sebuah modul yang bernama ESP8266 dimana fungsi modul tersebut adalah dapat menghubungkan alat pada internet tanpa menambah modul eksternal.
Saat ini pada umumnya Vending Machine masih belum bisa memonitoring stok, data transaksi dan jumlah item yang terjual setiap bulannya. Oleh sebab itu perlu adanya kolaborasi antara vending machine (alat) dengan internet untuk dapat memonitoring status dari vending machine itu sendiri dimanapun dan kapanpun.

$$
\text { Sistem pembayaran Vending }
$$

Machine pada umumnya masih menggunakan uang kertas untuk melakukan transaksi pada alat tersebut, dimana metode ini masih belum efektif dikarenakan saat melakukan transaksi tidak bisa memberikan uang kembalian dan tidak semua uang kertas bisa terbaca oleh mesin [4]. Dengan adanya teknologi saat ini yang bisa melakukan transaksi hanya menggunakan kartu atau biasanya yang disebut E-Money, dapat membuat nilai lebih yang bisa membuat pelanggan tidak perlu menyiapkan uang pas atau memilih uang yang masih bagus untuk melakukan transaksi.

Penelitian yang berkaitan dengan sistem pada Vending Machine sudah pernah dilakukan sebelumnya, yang berjudul "Rancang Bangung Vending Machine Menggunakan QR Code Berbasis Mikrokontroller". Vending Machine yang dibangun pada penelitian ini menggunakan sebuah modul Bluetooth dengan tipe HC-05 sebagai sistem komunikasi dua arah antara alat dengan calon pembeli menggunakan smartphone. Vending Machine tersebut menggunakan Arduino dengan tipe Nano sebagai otak atau pusat pengolah data sensor pada alat hingga pengendali servo. Realisasi pada penelitian ini, Modul bluetooth pada Vending Machine dapat membaca pesan serial yang dikirim oleh smartphone pengguna atau pembeli. Pesan serial yang diterima oleh bluetooth selanjutnya akan ditampilkan pada serial 
monitor. Pada sistem yang dibuat, pembelian hanya dapat diakses setelah program pada alat melakukan scanning terhadap salah satu QR Code dari masing masing minuman yang tersedia. Selanjutnya pembeli menekan tombol scan, program akan melakukan proses scanning. Setelah QR Code item yang dipilih sudah terbaca, maka akan menampilkan data dari minuman tersebut dan tombol beli akan menjadi aktif dan dapat diakses oleh pembeli. Ketika tombol beli ditekan dan minuman yang di pilih terdeteksi tersebut memiliki status tersedia atau ada dalam Vending Machine, maka sistem akan mengirimkan data minuman tersebut menuju Vending Machine melalui bluetooth dan sistem akan menjalankan fungsi pengurangan jumlah saldo pengguna sesuai harga minuman yang terdeteksi. Setelah berhasil program akan mengirimkan data transaksi penjualan ke database untuk mengirimkan data stok terbaru ke database secara online [5]. Yang membedakan penelitian sebelumnya dengan yang akan dibuat adalah sistem pengiriman data yang digunakan, dimana penelitian sebelumnya melalui Bluetooth sedangkan penelitian yang akan dibuat meggunakan konektivitas internet.

Penelitian selanjutnya yang berjudul "Vending Machine Using 8051 Microcontroller". Mesin yang sistem pembayarannya menggunakan uang koin. Ada slot untuk koin yang terhubung ke mikrokontroler. User Interface digunakan untuk pengeluaran koin dan pengeluaran produk. Relay digunakan untuk mengontrol motor dc 60 RPM untuk pengiriman produk. Program ini ditulis pada prosesor AT89S52 dan diunduh menggunakan perangkat lunak Flash Magic untuk memilih produk, memeriksa koin, dan mengendalikan relai untuk pengeluaran produk. Setelah memasok tegangan AC, penyearah mengubahnya menjadi tegangan DC dan regulator tegangan digunakan untuk memperlancar tegangan dengan nilai tertentu. Setelah koin dimasukkan, pulsa diterima di mikrokontroler yang sudah dipasok dengan tegangan DC tetap, Kelemahan dalam sistem ini ialah belumnya terhubung dengan internet oleh sebab itu pada penelitian ini menggunakan mikrokontroller NodeMCU ESP8266 yang dapat menyimpan data sementara pada memori flash dan dapat terhubung dengan internet [6]. Yang membedakan penelitian sebelumnya yang menggunakan sistem pembayaran menggunakan uang koin, kini pada penelitian yang akan dibuat sistem pemabayarannya di ganti menggunakan kartu atau E-Money, dimana keuntungan yang diperoleh sangat banyak dari pada masih menggunakan uang koin.

Penelitian lainnya yang berkaitan dengan sistem pembayaran pada Vending Machine pernah dilakukan sebelumnya dengan judul "Rancang Bangun Prototype Mesin Penjualan Sirup Otomatis Dengan Uang Logam Berbasis Arduino" [7]. "Vending Machine berbasis RFID" [8]. "Rancang Bangun Vending Machine menggunakan sensor Loadcell untuk Mendeteksi Input Uang Logam" [9]. Dari kelemahan Vending Machine pada penelitian sebelumnya, dibuatkanlah sistem yang akan digabungkan dengan teknologi IoT (Internet of Things). Sistem yang dimaksud adalah sebuah perangkat Prototipe Vending Machine yang berbasis Microcontroller sehingga dapat menerapkan konsep IoT, dimana pengelola dapat berinteraksi dengan perangkat ini melalui internet. Maka diangkatlah penelitian yang berujudul rancang bangun prototipe sistem monitoring Vending Machine berbasis Internet of Things. 


\section{TINJAUAN PUSTAKA}

\subsection{Internet of Things}

Internet of Things atau yang sering di dengar dengan istilah IoT merupakan sebuah metode yang bertujuan untuk memperluas manfaat - manfaat yang ada dari konektivitas internet. Dengan berkembangnya internet tersebut bukan hanya smartphone atau komputer saja yang dapat terhubung dengan internet. Namun berbagai macam benda - benda dapat terkoneksi dengan internet. Sebagai contoh dapat berupa mesin produksi, mobil, dan termasuk benda nyata apa saja yang semuanya tersambung ke jaringan internet[10].

\subsection{Vending Machine \\ Vending Machine adalah suatu}

mesin penjual otomatis yang dapat mengeluarkan barang atau minuman yang diinginkan oleh pembeli. Secara garis besar cara kerja mesin ini cukup mudah, Pembeli hanya perlu memasukkan sejumlah koin tertentu sesuai harga dari item yang ingin di beli dan menekan tombol sesuai dengan item yang dipilih sebelumnya. Dengan majunya ilmu pengetahuan dan teknologi yang tercipta saat ini sangat berperan penting dalam terciptanya prototipe ini. Bisa saja jika suatu saat mesin penjual otomatis atau vending machine ini akan menggantikan peran toko dalam perdagangan [11].

\subsection{Mikrokontroler Arduino Uno dan NodeMCU ESP8266}

Mikrokontroler adalah sebuah otak dari suatu alat, yang berbentuk sebuah chip IC (Integrated Circuit) dan memliki fungsi untuk melakukan tugasnya atau perintah tertentu sesuai dengan skema yang akan dibuat. IC pada Mikrokontroller terdiri dari satu atau lebih Inti Prosesor (CPU), Memori (RAM dan ROM) serta perangkat INPUT dan OUTPUT yang dapat ditanamkan pada Mikrokontroller [12]. Arduino UNO merupakan salah satu mikrokontroller yang berfungsi bertindak seperti sebuah komputer. Mikrokontroller ini dapat dimanfaatkan untuk membuat rangkaian elektronik dari yang sederhana hingga yang kompleks sekalipun [13]. NodeMCU ESP8266 sama halnya dengan Arduino UNO yang membedakan dari kedua mikrokontroller ini adalah NodeMCU ESP8266 mendukung konektifitas internet dan daya simpan data yang lebih besar yang tertanam pada memori flash [14]. Pada penelitian ini menggunakan dua buah mikrokontroller pada masing - masing alatnya dimana fungsi Arduino UNO sebagai pengolah data dan NodeMCU ESP8266 berfungsi sebagai penguhung dengan internet agar data dapat disimpan pada database secara online.

\subsection{Sensor Radio Frequency Identification \\ RFID (Radio Frequency}

Identification) merupakan salah satu dari banyak bentuk perkembangan teknologi nirkabel atau juga sering disebut dengan wireless (tanpa kabel). Cara kerja RFID dengan cara memberikan gelombang frekuensi transmisi radio untuk mengidentifikasi suatu objek yang bisa disebut RFID tag. Sistem identifikasi yang ada pada RFID merupakan tipe sistem yang bersifat auotomatis, data yang akan ditransmisikan oleh RFID tag selanjutnya dapat terbaca oleh suatu reader pada RFID, Selanjutnya data dapat diproses sesuai dengan kebutuhan yang diperlukan dari aplikasi yang telah dibuat [15]. Pada penelitian ini sensor RFID digunakan untuk membaca dan menulis nilai saldo pada kartu. 


\section{METODOLOGI PENELITIAN}

Metode penelitian merupakan aspek dasar dalam pengerjaan suatu penelitian. Metodologi penelitian berisi tahapan tahapan atau gambaran dari pembuatan suatu penelitian.

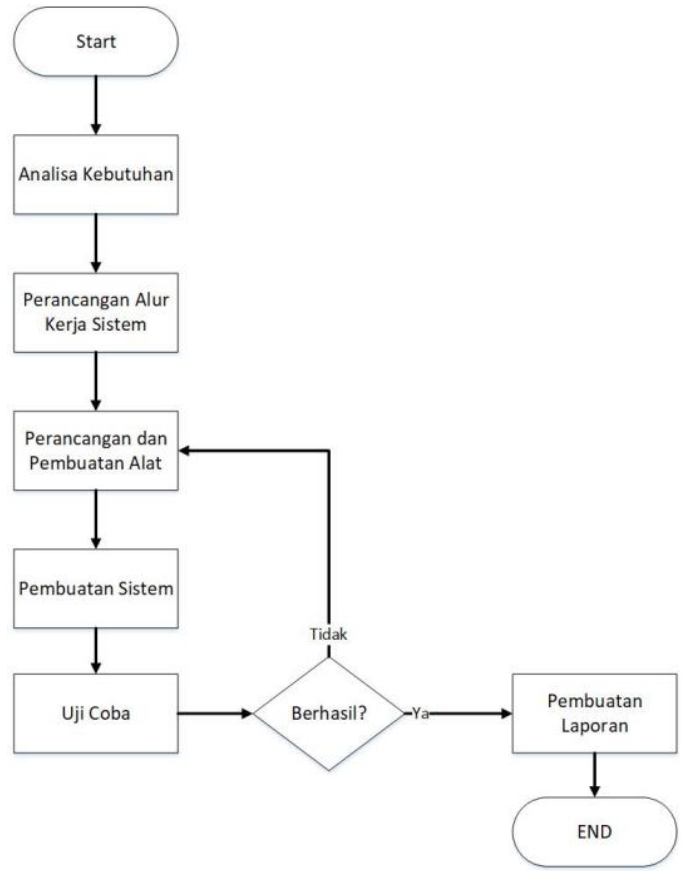

Gambar 1. Metodologi Penelitan Sumber : Dokumen Pribadi

Gambar 1. merupakan tahapan dari metodologi penelitian yang digunakan dalam penelitan. Pelaksanaan kegiatan terdiri dari enam tahapan, yaitu analisa kebutuhan, perancangan alur kerja sistem, perancangan desain perangkat keras, pembuatan sistem, uji coba dan pembuatan laporan.

\subsection{Gambaran Umum Sistem}

Pada saat ini setiap orang yang hendak membeli item pada vending machine memiliki kendala yaitu tidak membawa uang pas dan itu membuat calon pembeli tidak jadi melakukan pembelian pada vending machine tersebut, maka diperlukannya sistem pembayaran menggunakan kartu (E-money) dan dari pihak pengelola pun masih kesulitan mengecek stok yang terdapat dalam vending machine itu sendiri maka di perlukannya penerapan Iot (Internet of Things) pada vending machine. Sistem ini memungkinkan menambah efisiensi dalam pihak pengelola, dimana tidak diperlukannya lagi pengecekan stok manual pada alat dan menghitung manual penjualan yang terjadi tiap bulannya dan jika ada item yang kosong atau habis maka ada notifikasi pada bot telegram bahwa salah satu item kehabisan stok, jika petugas sudah menambahkan makanan pada alat, petugas bisa menambahkan stok pada aplikasi web. Ilustrasi dari prototipe monitoring vending machine berbasis IoT dapat dilihat pada gambar berikut.

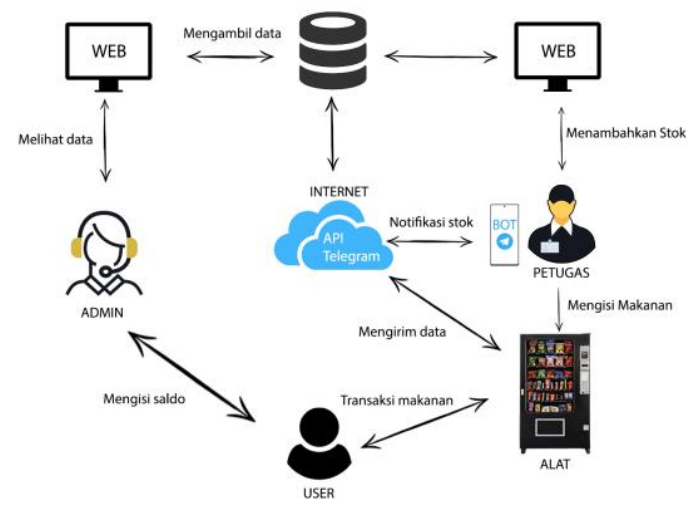

Gambar 2. Gambaran Umum Sistem Sumber : Dokumen Pribadi

Gambar 2 merupakan gambaran umum sistem yang dimana user dapat melakukan pengisian saldo dan melakukan transaksi pada alat vending machine jika stok yang di pilih sedang kosong maka alat akan mengirimkan notifikasi bot telegram bahwa item yang dipilih sedang kosong, jika stok ada maka akan muncul nama makanan dan harga pada layar lcd, user akan di minta menempelkan kartu E-money untuk melanjutkan transaksi, jika transaksi berhasil alat akan mendorong makanan keluar dan mengirimkan data transaki ke data base. 
Admin dapat melakukan pengisian saldo pada user dan monitoring terhadap data penjualan dan stok makanan pada aplikasi web. Jika salah satu makanan habis maka petugas akan mendapatkan notifikasi bahwa salah satu mekanan sedang habis, petugas akan langsung mengisi makanan pada vending machine dan memperbarui stok pada aplikasi web. Petugas juga dapat melihat stok makanan melalui aplikasi bot telegram.

\subsection{Diagram Blok Sistem}

Guna memperjelas dari setiap komponen - komponen yang digunakan sebagai penunjang dari bekerjanya alat vending machine berbasis IoT dapat dilihat pada gambar berikut.

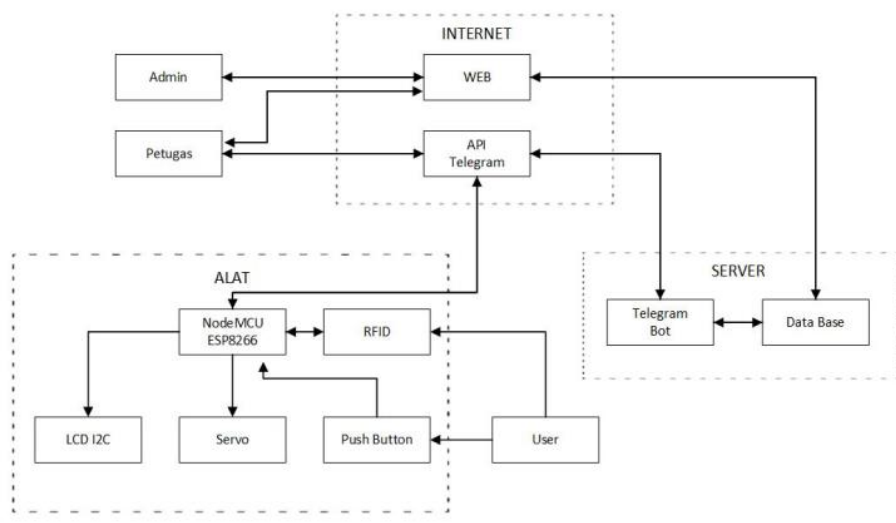

Gambar 3. Diagram Blok Sistem

Sumber : Dokumen Pribadi

Gambar 3 merupakan tampilan dari diagram blok sistem, blok alat merupakan blok yang dapat melakukan berjalannya transaksi yang di lakukan oleh user atau calon pembeli sehingga memudahkan calon pembeli melakuan transaksi yang di tampilkan melalui layar LCD, kemudian RFID sebagai sensor pembaca saldo kartu, jika saldo berhasil terbaca dan melakukan pemotongan saldo selanjutnya yang terakhir servo akan berputar dan mendorong makanan. Selain itu blok alat dapat menerima dan mengirim pesan via bot telegram ke pada admin bahwa stok ada yang sedang kosong atau habis.

Blok server terdiri dari dua yaitu database yang berfungsi untuk menyimpan data dan bot telegram yang bertugas menghandle layanan bot telegram, Selain itu terdapat blok internet yang terdiri dari web yang digunakan untuk melakukan penambahan stok dan melihat data penjualan, yang terakhir yaitu API telegram yang bertugas mengirim pesan melalui bot telegram.

\subsection{Pemodelan Sistem}

Pemodelan sistem merupakan bentuk penyederhanaan dari suatu elemen dan komponen - komponen yang sangat kompleks untuk memudahkan pemahaman dari informasi yang dibutuhkan dan fungsional kepada pengamat sistem. Adapun pemodelan sistem dari prototipe prototipe vending machine berbasis IoT menggunakan gambaran Use Case, Diagram Context, PDM, Struktur Data Tabel, dan SOP Diagram. 

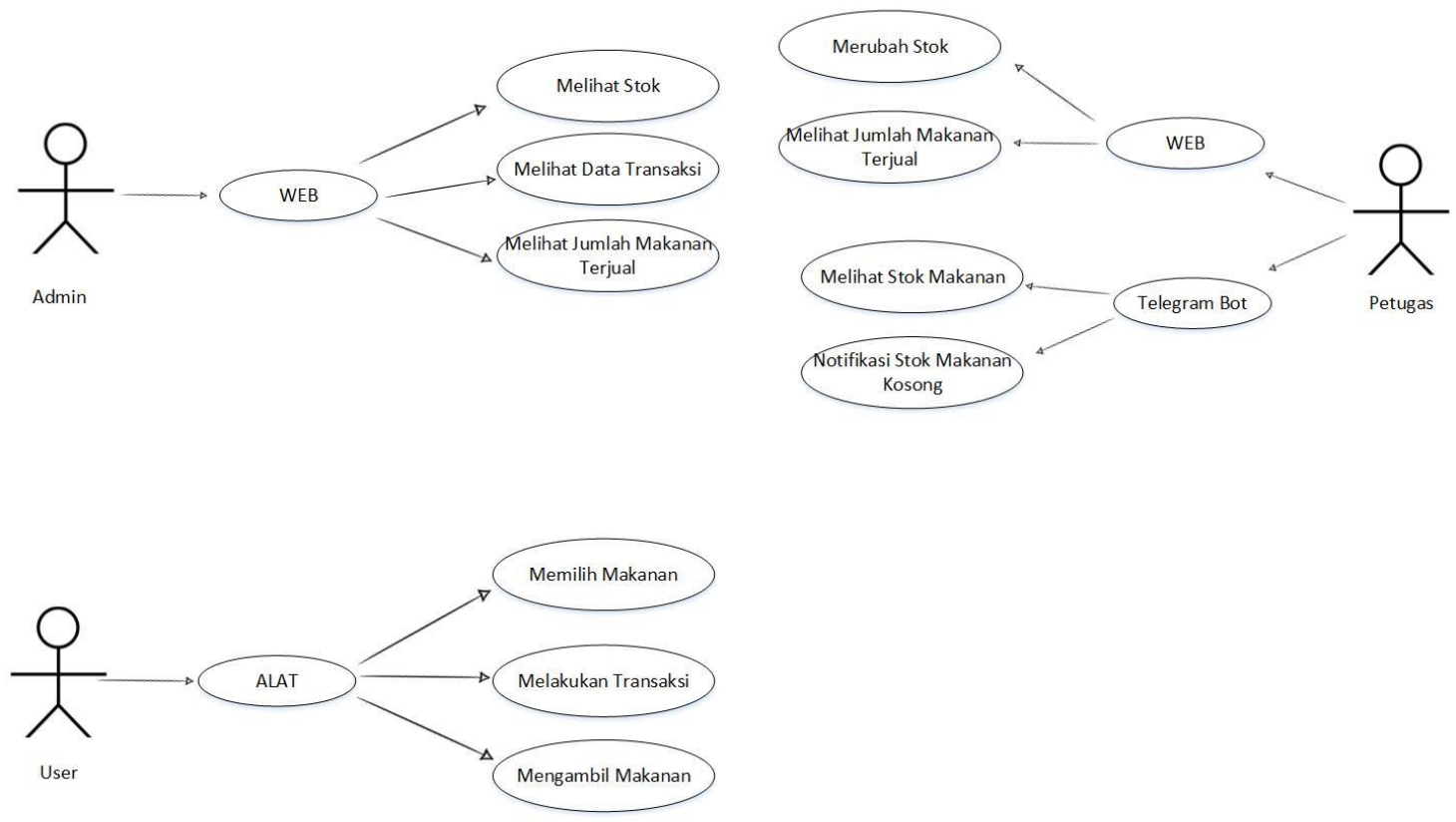

Gambar 4. Use Case

Sumber : Dokumen Pribadi

Gambar 4 merupakan tampilan dari use case vending machine berbasis Internet of Things. Adapun dua aktor yang berperan dalam sistem yaitu user atau calon pembeli, admin dan petugas. Setiap aktor memiliki perannya masing - masing untuk menggunakan fungsional yang disediakan oleh sistem. 


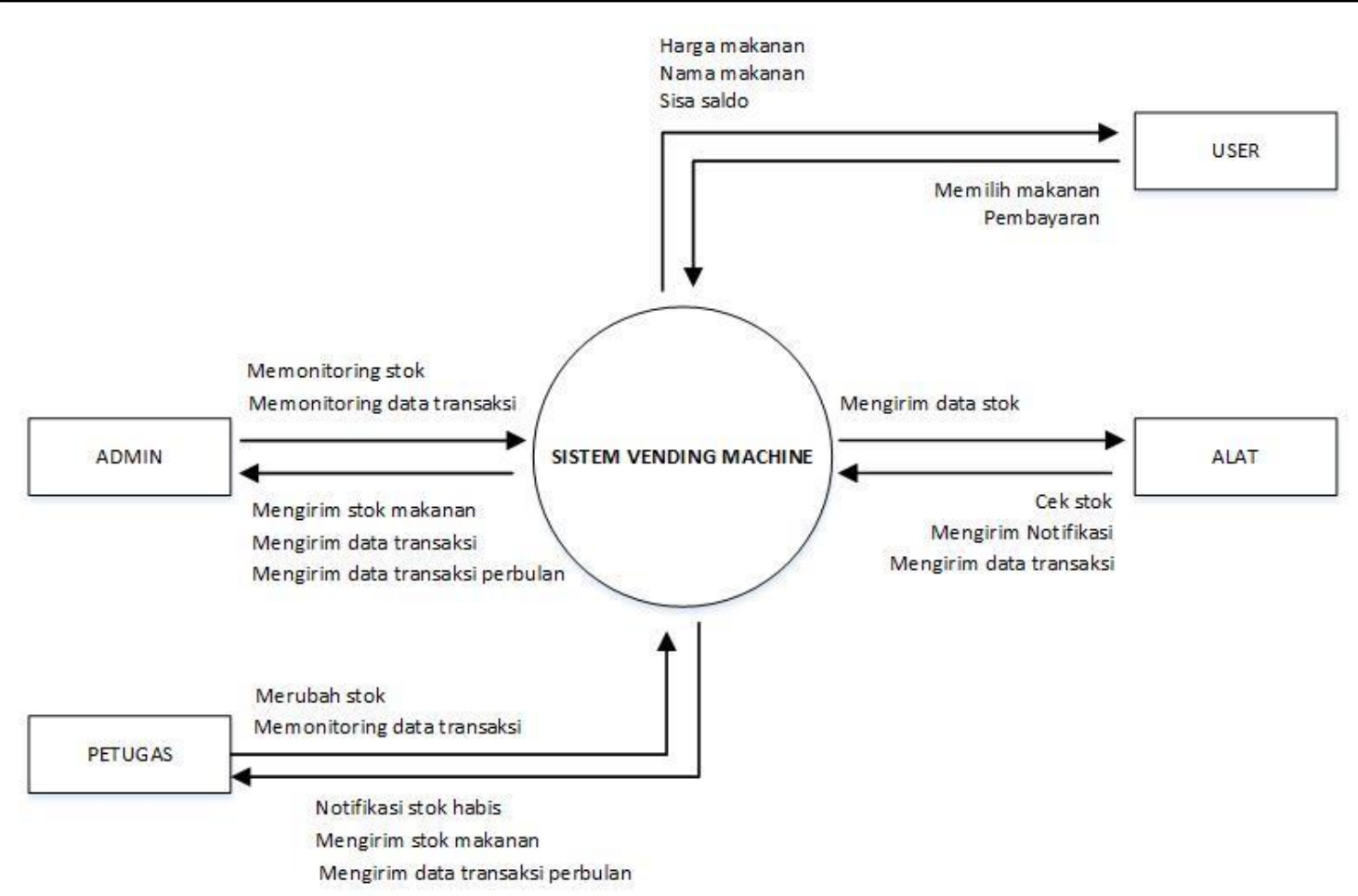

Gambar 5. Diagram Konteks

Sumber : Dokumen Pribadi

Gambar 5 terdapat tiga entitas antara lain admin, petugas dan alat, dari ke tiga entitas tersebut saling berelasi dalam proses sistem Vending Machine berbasis Internet of Things.

\subsection{Analisa Kebutuhan Perangkat Keras IoT \\ Hardware atau perangkat keras yang} digunakan dalam membangun prototipe sistem monitoring Vending Machine berbasis Internet of Things (IoT) ini tunjukan pada tabel berikut.

Tabel 1. Kebutuhan Perangkat Keras Prototipe Vending Machine

\begin{tabular}{|l|l|l|}
\hline No. & Hardware & Kegunaan \\
\hline 1. & $\begin{array}{l}\text { NodeMCU } \\
\text { \& Arduino } \\
\text { UNO }\end{array}$ & $\begin{array}{l}\text { Sebagai } \\
\text { minikontroller dan } \\
\text { pemrosesan data. }\end{array}$ \\
\hline 2. & $\begin{array}{l}\text { Sensor } \\
\text { RFID }\end{array}$ & $\begin{array}{l}\text { Sebagai prosesnya } \\
\text { transaksi. }\end{array}$ \\
\hline
\end{tabular}

\begin{tabular}{|l|l|l|}
\hline 3. & PushButton & $\begin{array}{l}\text { Sebagai tombol } \\
\text { untuk memlilih } \\
\text { makanan. }\end{array}$ \\
\hline 4. & Breadboard & $\begin{array}{l}\text { Papan untuk } \\
\text { merangkai rangkaian } \\
\text { elektronik. }\end{array}$ \\
\hline 5. & LCD I2C & $\begin{array}{l}\text { Menampilkan harga } \\
\text { yang akan di } \\
\text { bayarkan. }\end{array}$ \\
\hline 6. & $\begin{array}{l}\text { Motor } \\
\text { Servo }\end{array}$ & $\begin{array}{l}\text { Sebagai penggerak } \\
\text { untuk mengeluarkan } \\
\text { makanan }\end{array}$ \\
\hline 7. & Buzzer & $\begin{array}{l}\text { Sebagai indicator } \\
\text { suara saat melakukan } \\
\text { transaksi. }\end{array}$ \\
\hline 8. & $\begin{array}{l}\text { Kabel } \\
\text { Jumper } \\
\text { Male tonghubungkan } \\
\text { Male }\end{array}$ & $\begin{array}{l}\text { komponen electronic } \\
\text { pada modul-modul } \\
\text { lainnya. }\end{array}$ \\
\hline 9. & $\begin{array}{l}\text { Kabel } \\
\text { Jumper } \\
\text { Male }\end{array}$ & $\begin{array}{l}\text { Menghubungkan } \\
\text { komponen electronic } \\
\text { pada modul-modul }\end{array}$ \\
\hline
\end{tabular}




\begin{tabular}{|c|c|c|}
\hline & Female & lainnya. \\
\hline 10. & $\begin{array}{l}\text { Kabel } \\
\text { Jumper } \\
\text { Female to } \\
\text { Female }\end{array}$ & $\begin{array}{l}\text { Menghubungkan } \\
\text { komponen electronic } \\
\text { pada modul-modul } \\
\text { lainnya. }\end{array}$ \\
\hline
\end{tabular}

Sumber : Dokumen Pribadi

\subsection{Skema Prototipe}

Skema protoptipe berfungsi untuk menggambrakan rangkaian - rangkain modul 1 dengan modul yang lainnya. Adapun skema prototipe pada alat ini dapat dilihat pada gambar berikut.

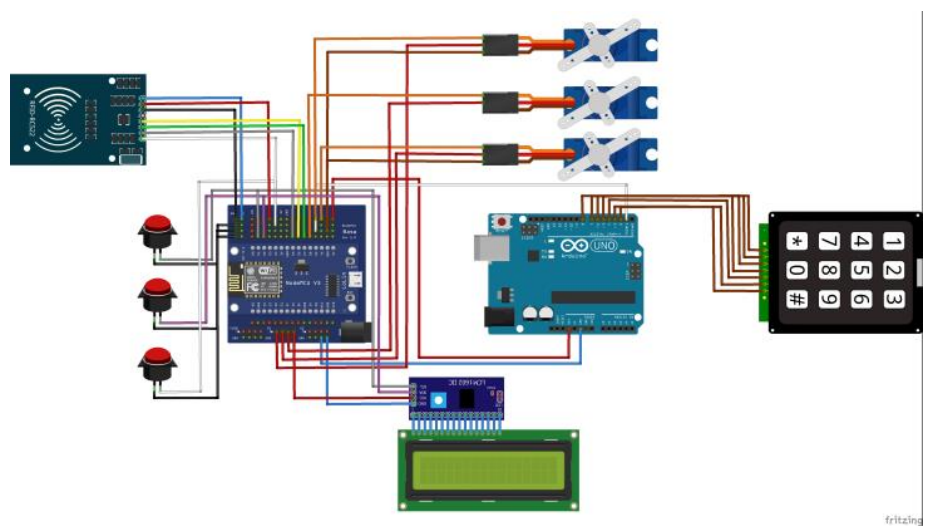

Gambar 6. Skema Prototipe Vending Machine

Sumber : Dokumen Pribadi

Gambar 6 menjelaskan rangkaian modul - modul pada alat vending machine antara lain, nodemcu yang bertugas sebagai memproses data mulai dari memilih makanan, melakukan pemotongan saldo dan mengeluarkan makanan, arduino yang berfungsi untuk mengirim data jumlah item yang di beli melalui keypad.

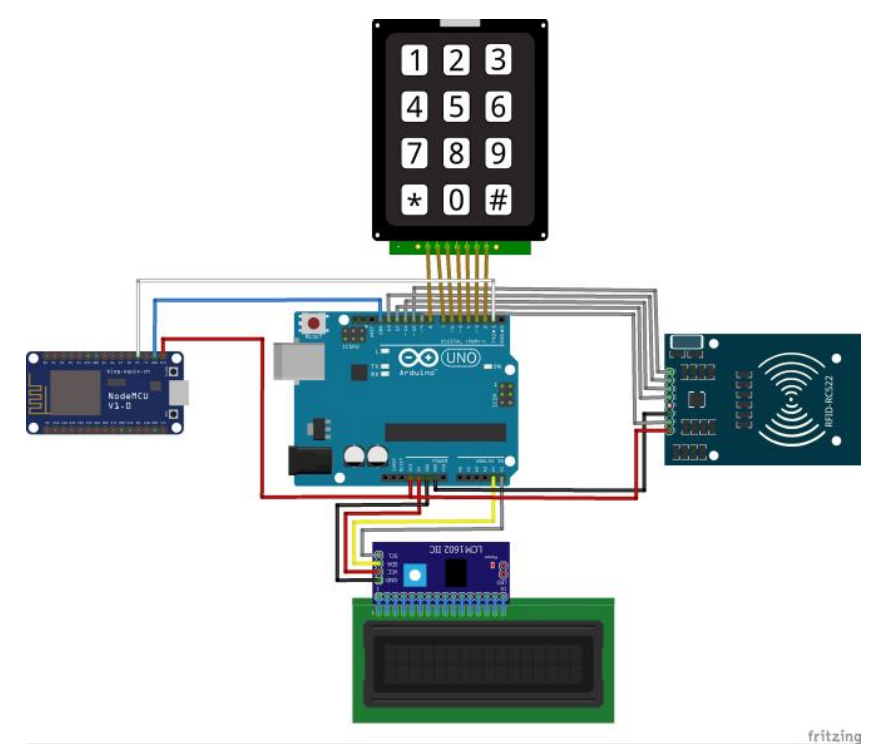

Gambar 7. Skema Prorotipe Pengisian Saldo

Sumber : Dokumen Pribadi

Gambar 7 menjelaskan rangkaian modul - modul pada alat pengisian saldo, beda halnya dengan racangan alat vending machine, pada rangkaian ini Arduino yang memiliki peran penting sebagai pemeroses dari transkasi yang dilakukan ketika pengisian saldo, dan nodemcu berfungsi sebagai penerima data dan mengirimkan data terserbut ke database.

\section{HASIL DAN PEMBAHASAN \\ 4.1 Realisasi Perancangan Alat dan Pengujian \\ Realisasi hasil perancangan alat} dilakukan untuk penerapan dari rancangan yang telah dibuat dan membangun rancangan sistem tersebut secara nyata. Berikut merupakan hasil rancangan hardware dari prototipe vending machine berbasis internet of things. 


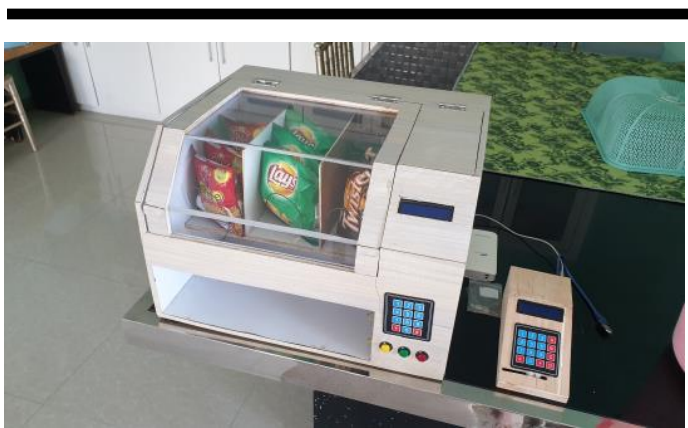

Gambar 8. Realisasi Prototipe Vending Machine dan Pengisian Saldo Sumber : Dokumen Pribadi

\subsection{Pengujian Sistem}

Pengujian sistem sangat penting dilakukan untuk mengetahui apakah sistem yang sudah dibuat dapat berjalan sesuai skema yang telah ditentukan. Pengujian sistem monitoring pada vending machine berbasis internet of things dilakukan dengan melakukan beberapa pengujian seperti push button, pengujian servo dan pengujian wifi dengan modul ESP8266. Berikut penjelasan secara mendetail mengenai pengujian pada penelitian ini.

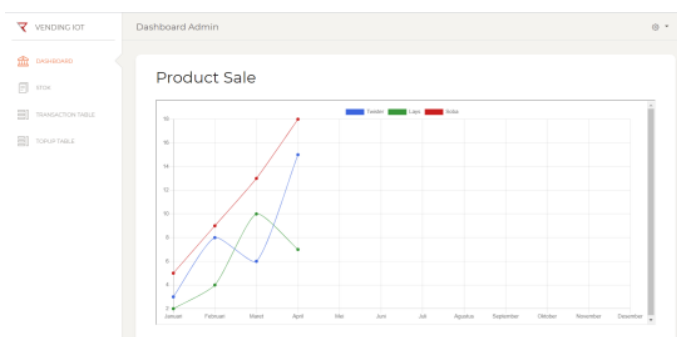

Gambar 9. Tampilan Website

Sumber : Dokumen Pribadi

Gambar 9 merupakan tampilan website, dimana di dalamnya terdapat beberapa halaman seperti dashboard yang berfungsi melihat statistik penjualan, halaman stok untuk memonitoring stok terkini, tabel transaksi untuk melihat transaksi yang terjadi dan tabel topup untuk melihat transaksi pengisian saldo.

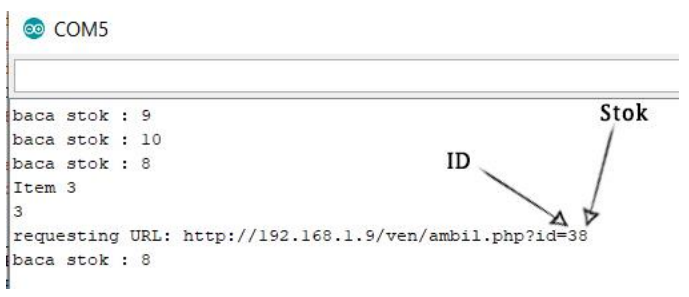

(a)

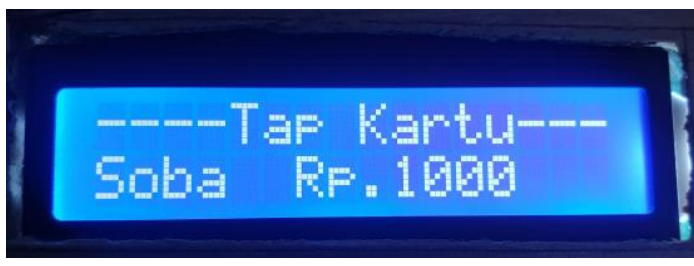

(b)

Gambar 10. (a) Tampilan Serial Monitor (b) Tampilan lcd

Sumber : Dokumen Pribadi

Gambar 10 (a) dan (b) merupakan pengujian dari sistem push button dimana saat pelanggan memilih makanan atau menekan tombol, selanjutnya id makanan dari tombol tersebut akan dikirimkan ke sistem untuk mengecek ketersediaan stok makanan tersebut.

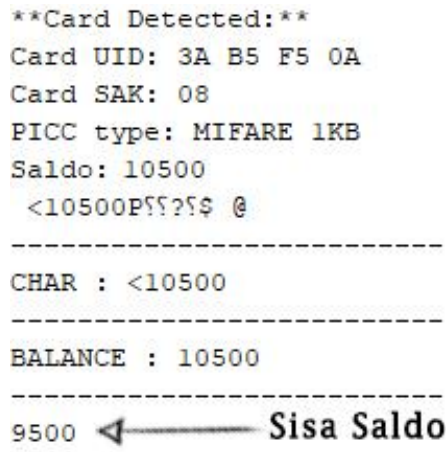

(a)

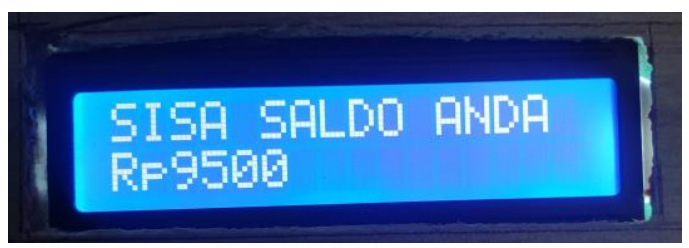

(b)

Gambar 11. (a) Pemotongan Saldo (b) Tampilan Saldo Terakhir Sumber : Dokumen Pribadi 
Gambar 11 (a) dan (b) merupakan pengujian pemotongan saldo, dimana user sudah memilih makanan sebelumnya dan di lakukan pengecekan stok. Nilai pada kartu bersifat char dimana harus melakukan konversi ke dalam integer dulu sebelum melakukan pemotongan saldo, Tahapan selanjutnya proses pemotongan saldo sesuai harga dari id makana tersebut.

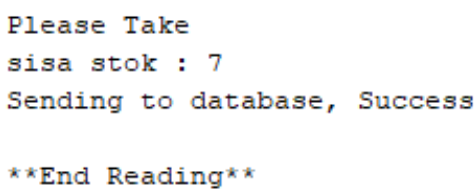

(a)

\section{Transaction Table}

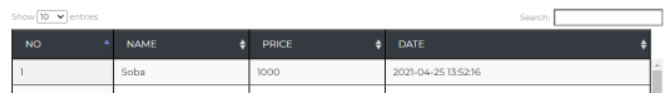

(b)

Gambar 12. (a) Kirim Data Transaksi

(b) Data Berhasil Tersimpan Sumber : Dokumen Pribadi

Gambar 12 (a) dan (b) merupakan pengujian dari sistem mengirim data, Jika transaksi sukses, maka sistem akan mengirim data id makanan untuk di lakukannya proses pengurangan stok, menambahkan data penjualan dan menambahkan data transaksi ke dalam database.

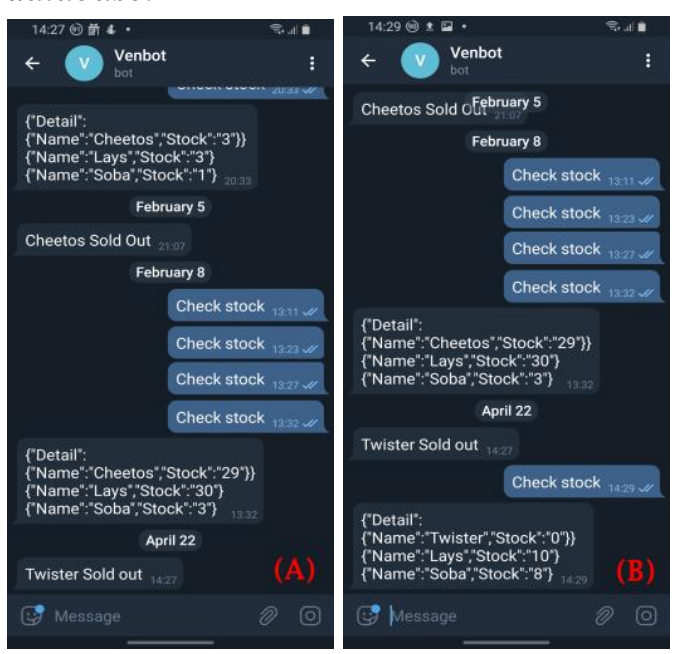

Gambar 13. Pengujian Telegram Bot Sumber : Dokumen Pribadi
Gambar 13 (a) merupakan kondisi sistem mengecek stok makanan 0 maka sistem akan mengirimkan notifikasi stok makanan dengan id tersebut sedang kosong. Pada Gambar 13 (b) petugas melakukan pengecekan stok melalui bot telegram dengan perintah cek stock, maka sistem akan menangkap dan mengambil data stok lalu mengirimkan melaui bot telegram.

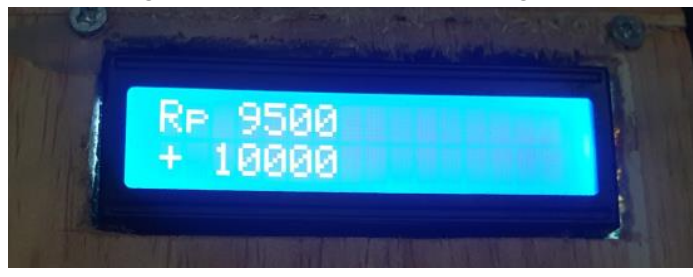

(a)

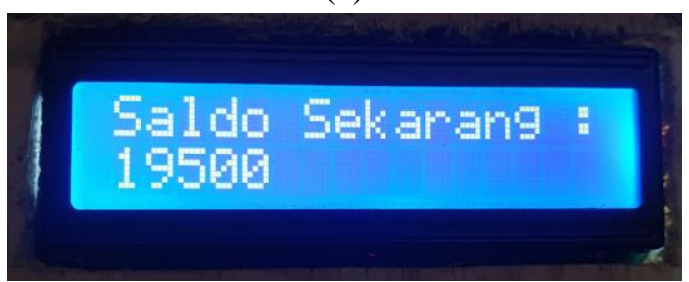

(b)

Topup Table

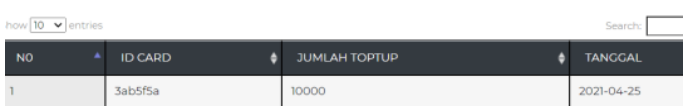

(c)

Gambar 14. (a) Proses Penambahan Saldo (b) Hasil Saldo Akhir (c) Berhasil

Tersimpan

Sumber : Dokumen Pribadi

Gambar 14 (a) meruapakan gambar yang melakukan proses pengujian pengisian saldo pada kartu. Alat akan membaca nilai saldo sebelumnya 9500 dan menambahkan nilai yang di inputkan 10.000 total saldo menjadi 19500 seperti pada Gambar 13 (b). Selanjutnya Gambar 13 (c) adalah hasil setelah data id kartu beserta nominal topup dikirimkan menuju nodemcu dan dikirimkan ke database. 


\subsection{Pengujian Putaran Servo}

Mekanisme pengujian

servo, merupakan pengujian yang melakukan transaksi pada alat dengan cara berturut turut sampai batas sample yang di perlukan. Hasil Pengujian alat dapat dilihat pada tabel berikut.

Tabel 2. Hasil Pengujian Servo

\begin{tabular}{|l|l|l|l|c|}
\hline No & Nama & Harga & Tanggal & Ket. \\
\hline 1 & Lays & 2000 & $\begin{array}{l}2021- \\
04-25\end{array}$ & $\checkmark$ \\
\hline 2 & Lays & 2000 & $\begin{array}{l}2021- \\
04-25\end{array}$ & $\checkmark$ \\
\hline 3 & Lays & 2000 & $\begin{array}{l}2021- \\
04-25\end{array}$ & $\checkmark$ \\
\hline 4 & Lays & 2000 & $\begin{array}{l}2021- \\
04-25\end{array}$ & $\checkmark$ \\
\hline 5 & Lays & 2000 & $\begin{array}{l}2021- \\
04-25\end{array}$ & $\checkmark$ \\
\hline 6 & Lays & 2000 & $\begin{array}{l}2021- \\
04-25\end{array}$ & $\checkmark$ \\
\hline 7 & Lays & 2000 & $\begin{array}{l}2021- \\
04-25\end{array}$ & $\mathrm{x}$ \\
\hline 8 & Lays & 2000 & $\begin{array}{l}2021- \\
04-25\end{array}$ & $\checkmark$ \\
\hline 9 & Lays & 2000 & $\begin{array}{l}2021- \\
04-25\end{array}$ & $\checkmark$ \\
\hline 10 & Lays & 2000 & $\begin{array}{l}2021- \\
04-25\end{array}$ & $\checkmark$ \\
\hline 11 & Lays & 2000 & $\begin{array}{l}2021- \\
04-25\end{array}$ & $\checkmark$ \\
\hline 12 & Lays & 2000 & $\begin{array}{l}2021- \\
04-25\end{array}$ & $\checkmark$ \\
\hline 13 & Lays & 2000 & $\begin{array}{l}2021- \\
04-25\end{array}$ & $\checkmark$ \\
\hline 14 & Lays & 2000 & $\begin{array}{l}2021- \\
04-25\end{array}$ & $\checkmark$ \\
\hline 15 & Lays & 2000 & $\begin{array}{l}2021- \\
04-25\end{array}$ & $\checkmark$ \\
\hline
\end{tabular}

Sumber : Dokumen Pribadi

Pada Tabel 2 pengujian di atas dengan menguji satu jenis makanan dengan melakukan $15 x$ transaksi secara berturut - turut terdapat satu kegagalan saat mengeluarkan makanan.

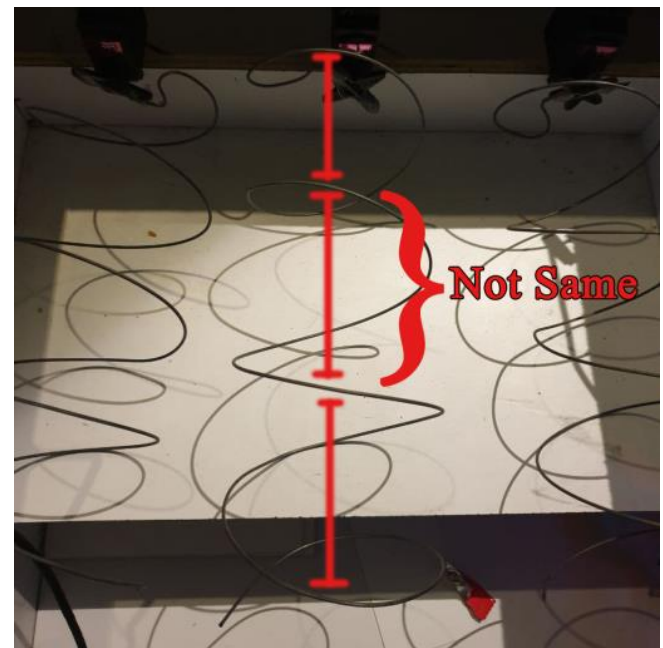

Gambar 15. Kawat Pendorong Sumber : Dokumen Pribadi

Gambar 15 menjelaskan lingkaran kawat yang masih belum presisi atau lingkaran dari masing - masing kawat belum sesuai dikarenakan untuk membuat lingkaran tersebut masih memakai alat seadanya hal tersebut yang meyebabkan terjadinya gagal saat proses mendorong makanan keluar seperti pada tabel 2 .

\section{KESIMPULAN}

Dari pemaparan dan pengujian yang telah dilakukan dapat disimpulkan sebegai berikut.

1. Dengan adanya inovasi gabungan dari suatu alat pembelian otomatis dengan konsep Internet of Things dapat menambah nilai lebih suatu alat tersebut dan memberikan keuntungan kepada pihak pengelola untuk lebih mudah untuk memonitoring melalui internet.

2. Merubah sistem pembayaran yang sebelumnya menggunakan uang koin maupun uang kertas menjadi sebuah kartu yang membuat lebih efisien, dimana calon pembeli tidak perlu memilih uang pas maupun melihat 
kondisi uangnya terlebih dahulu saat ingin melakukan transaksi.

3. Pada pengujian putaran servo memang terdapat kendala pada percobaan ke 7 dimana makanan tidak dapat keluar atau terjatuh dikarenakan lingkaran kawat yang tidak sama dengan kawat yang lain, akan tetapi dari $15 x$ percobaan hanya terdapat $1 \mathrm{x}$ kegagalan merupakan hasil yang sudah lumayan bagus.

\section{SARAN}

Dari kekurangan yang dapat dari penelitian ini adapun saran yang dapat diberikan untuk penelitian selanjutnya yaitu sebagai berikut.

1. Pada penelitian ini masih pada tahap prototipe, oleh sebab itu diharapkan kedepannya dapat menambah jenis maupun jumlah makanan yang dapat di jual dalam alat tersebut.

2. Untuk kawat pendorong makanan dapat di rubah yang sebelumnya kawat menjadi plastik yang di cetak menggunakan 3D printer agar ukuran lingkaran dari masing - masing jenis makanan sesuai dan bisa meminimalisir kegagalan dalam pengujian sebelumnya.

\section{DAFTAR PUSTAKA}

[1] Dadang Sujana, Q.M., Adim Nuraidin, Muhammad Abdul Rosip, Wahyu Sulistianto, Komparasi Analisa Sistem Simulasi Vending Machine Automatic Cash Money Dan E-Money Di Universitas Islam Syekh Yusuf Tangerang. Universitas Islam Syekh-Yusuf Tangerang, 2019.

[2] Efendi, Y., Internet of Thins Sistem Pengendalian Lampu Menggunakan Raspberry PI Berbasis Mobile. Jurnal Ilmiah Komputer, 2018.

[3] Satriadi, A., Perancangan Home Autimation Berbasis NodeMCU.
Transient. Jurnal Ilmu Teknik Elektro, 2019.

[4] Dodi S. Adiputra, Y.P., Heri Subagiyo, Mesin Penjual Softdrink Otomatis Berbasis ATMega8535. ELEMENTER. Jurnal Elektro dan Mesin Terapan, 2015. Vol. 1.

[5] Rizki Pradana Putra, I.G.A.P.R.A., Pratolo Rahardjo, Rancang Bangun Vending Machine Menggunakan QR Code Berbasis Mikrokontroller. Jurnal Spektrum, 2019. vol 6.

[6] Dour, S., Vending Machine Using 8051 Micro Controller. International Journal of Advance Reserch in Science and Enginering, 2017.

[7] Ikhwa, F., Rancang Bangun Prototipe Mesin Penjual Otomatis Dengan Uang Logam Berbasis Arduino. Teknik Informatika, Universitas PGRI Yogyakarta, 2015.

[8] Geri Khusari, A.F., Vending Machine Berbasis RFID. 2009.

[9] Ramadhan, A., Rancang Bangun Vending Machine menggunakan sensor Loadcell untuk Mendeteksi Input Uang Logam Berbasis Mikrokontroler. Universitas Andalas, 2018.

[10] Mehta, M., A Breakthroug in Wireless Sensor Network and Internet of Things. IJECET. International Journal of Electronics and Communication Engineering \& Technology, 2015.

[11] Purnomo, A., Perancangan dan Pembuatan Mesin Penjual Otomatis Menggunakan Relai Cerdas. ETD Mudammadiyah Surakarta, 2015.

[12] Dewi, N.H.L., Prototipe Smart Home Dengan Modul NodeMCU ESP8266 Berbasis IOT. Repositori Institusi Universitas Islam Majapahit, 2018.

[13] Destiarini, P.W.K., Robot Line Follower Berbasis Arduino UNO. Jurnal Informatika Universitas Baturaja, 2019.

[14] Rahmad Doni, M.R., Sistem Monitoring Tanaman Hidroponik Berbasis Iot (Internet of Thing) Menggunakan Nodemcu ESP8266. J- 
Sakti. Jurnal Sains Komputer \& Informatika, 2020. Vol. 4.

[15] Ridwan Alief, D., and Sudjadi,

Pemanfaatan Teknologi RFID

Melalui Kartu Identitas Dosen Pada

Prototipe Sistem Ruang Kelas

Cerdas. Transmisi, 2014. 